\title{
Kansalaisopistojen tehtäväkuvan muuttuminen tällä vuosisadalla
}

\author{
Auvo Karsikkaan lisensiaattitutkimus "Valtiovallan ja \\ kansanopistojen suhteet vuosina 1898-1979 ja \\ kansanopistolaitoksen tehtäväkuvan muuttuminen vuosina \\ 1946-1979" valmistui 1988 Tampereen yliopiston \\ kasvatustieteiden tiedekunnassa. \\ Julkaisemme yhteenvedonomaisesti sisällön pääpiirteitä itse \\ tutkimuksesta sek̉ä virallisen tarkastajan, professori \\ Aulis Alasen lausunnon tutkimuksesta.
}

Auvo Karsikkaan työn tutkimustehtävä oli kaksijakoinen: mitä tavoitteita valtiovallalla on ollut sen tukiessa ja säädellessä kansa. laisopistolaitoksen toimintaa ja mitkä ovat olleet johtavien opistoihmisten valtiovaltaan kohdistamat odotukset.

Ikäänkuin johdannoksi tulkittavan ensim. mäisen luvun jälkeen on toisessa ja kolman. nessa luvussa selvitetty valtiovallan ja kansa. laisopistolaitoksen suhdetta. Ne taas ovat olleet pohjana nimenomaan luvulle 4. Siinä on tutkittu opistojen tehtäväkuvaa ja sen muuttumista. Tietysti kummatkin tutkimustehtävän puolikkaat ovat mukana molemmissa osissa läpikäyvänä "juonena".

Valtion ja'opistoliikkeen suhdetta on tutkittu valtion opistoille antaman taloudellisen tuen ja normatiivisen tehtävän kautta. Valtio ei systemaattisesti tukenut ensimmäisiä enempää kuin toisiakaan autonomian ajan opistoja rahallisesti.

Itsenäisen Suomen laatima ensimmäinen opistolainsäädäntö edellyttää opistoilta nuoren valtion eheyttämistä työläisten sivistysta. soa kohottamalla ja sopeuttamalla heitä luo- tuun valtiojärjestelmään. Samalla valtio tuki selkeästi opistoja. Opistoliikkeen edustajat olivat itse luomassa sekä normatiivista tehtä. vää että pistojen talouden turvaavaa valtionapujärjestelmää.

Sodan jälkeen poikkeuksellisissa oloissa asetettu "uuden vasemmiston" sävyttämä työväenopistokomitea halusi työväenopistoista yhteiskunnallisen kasvatuksen instrumenttia, jolla nostettaisiin työväestön yhteiskunnallista tietämystä ja sitä kautta poliittista valtaa. Komitean työ oli pieni osa sodan jälkeistä taistelua siitä, mihin suuntaan Suomen poliittinen linja ja yhteiskunnallinen järjestelmä kehittyisivät.

Vuosien 1962-1963 opistolainsäädäntö väljensi opistojen normatiivista tehtävää. Opistojen tehtäviksi annettiin moniarvoisen yhteiskunta- ja kulttuuripolitiikan tukeminen.

Viime vuosikymmeninä valtion valvonta on lisääntynyt, vaikka valtiolla on nykyään kansalaisten mielipiteiden muokkaamiseen monin verroin opistolaitosta tehokkaammat välineet, $\mathrm{mm}$. radio ja televisio. 


\section{Lausunto}

Suomalaista kansanopistoa on valtakunnallisena organisaatiokokonaisuutena tutkittu vähän. Auvo Karsikkaan teema, opistolaitoksen normatiivisen tehtävän muotoutuminen valtion säätelyn ja opistokäytännön omien aktiivisten kehittäjien yhdysvaikutuksena, on sekä ajankohtainen että perspektiiviä avaava tutkimustehtävä. Karsikkaan työstä ilmenevä hyvä perehtyneisyys kohdealueeseen perustuu sekä omakohtaiseen osallistumiseen että opistolaitoksen koko historiaa ja nykyisyyttä valaisevan kirjallisuuden tuntemukseen. Kun tekijällä lisäksi on luontainen taipumus asettaa vakiintuneita käsityksiä kyseenalaisiksi, on pitkän työskentelyn tuloksena syntynyt raportti, joka merkittävällä tavalla rakentaa kokonaiskuvaa kansalaisopistojen yhteiskunnallisen tehtävän muuttumisesta.

Vastapainoksi on heti alkuun paikallaan kirjata joitakin tutkimuksen yleisiä rajoituksia.

- Tekijän vahvat ennakkokäsitykset ja -näkemykset ovat johtaneet siihen, että yleistävät päätelmät eivät kaikin kohdin tule riittävästi perustelluiksi.

- Tilastoaineiston käyttelyssä on kahdenlaisia puutteita. Ensinnäkin on nähty runsaasti vaivaa sellaisten tilastotietojen hankkimisessa, joiden käsittely ei oikein osu asetettujen ongelmien ytimeen. Toiseksi havaituista määrällisistä muutoksista tehdään monesti liian suoraviivaisia, toisinaan jo perusteiltaan kyseenalaisia tulkintoja ja päätelmiä. Tilastoaineiston teknisessäkin käsittelyssä on huomauttamisen varaa.

- Raportissa käsitellään paikoin perusteellisestikin kysymyksiä, jotka eivät kiinteästi liity kokonaisuuteen.

- Edellä mainitut puutteet heijastuvat myös esitystavassa, joka noudattelee niin ajallisesti kuin teemallisestikin hyppelevää, väljää assosiointia. Tärkeitäkin huomioita saattaa tällä tavoin tulla esiin toisessa asiayhteydessä kuin ao. kysymyksiä varsinaisesti käsitellään. Myös lähdeviitteiden esittäminen rönsyilee.

Tutkimuksessa on kaksi pääosaa. Opistolaitoksen ja sen tehtävien kehittämistä tarkastellaan kirjallisuuden ja dokumenttien varassa vuodesta 1898 eli ensimmäisen opiston perustamisesta lähtien pitäen silmällä valtion säätelyn osuutta tehtävien muotoutumisessa. Toisessa osassa analysoidaan opintoainejakautumien perustalla tosiasiallisen tehtäväkuvan muuttumista toisen maailmansodan jälkeen. Tämä kaksijakoisuus on perusteltua, kuten raportin I luvussa osoitetaan. Johdantoluvun alussa esitetty tehtävänmäärittely on täsmentymättömämpi kuin itse tutkimusta ohjaava kysymyksenasettelu. Johdantoluku olisi parantunut tiivistämisestä; esimerkiksi peruskäsitteiden määrittelyssä olisi mielestäni ollut parempi tyytyä esittelemään, missä merkityksessä käsitteitä käytetään omassa työssä.

Metodologisesti tutkimuksessa on yhdistetty historiallinen ja yhteiskunnallinen tarkastelutapa. Ratkaisuun on hyvät perusteet, mutta on ymmärrettävää, että sen toteuttaminen ei ole pulmattomasti onnistunut: yhdistäjä tulee ottaneeksi ikään kuin vierailijan vapauksia kummassakin suunnassa. Varsinkaan yhteiskunnallisen muutostaustan tarkkailu ei täytä kiitettävästi enempää historiatieteen kuin sosiologiankaan vaatimuksia.

Kansalaisopistolaitoksen historiallisen kehittymisen hahmottelussa (luku 2) tulevat joka tapauksessa esille sekä yhteiskunnallis-taloudelliset että aatehistorialliset yhteydet. Kovin perusteellista paneutumista taustoihin ei tässä yhteydessä ole kohtuullista vaatiakaan. Lisätutkimusta kaipaa esimerkiksi kysymys fennomanian ja liberalismin suhteesta työväenopistoon; epäilen Karsikkaan argu. mentoinnin pitävyyttä. Karsikkaan halu arvioida uudelleen Z. Castrenin sivistysnäkemystä on johtanut selvästi yksipuolisiinkin kärjistyksiin - "Suomen asukkaat oli kansalaistettava ... uuteen valkoiseen tasavaltaan" mutta väitteille C:n tietynlaisesta eliittisyy. destä on kyllä perusteita.

Vuosien 1926 ja 1938 lainsäädäntöprosesseihin olisi ollut $-\mathrm{mm}$. valtiopäiväasiakirjojen avulla - aihetta paneutua perusteellisemminkin.

Vuoden 1948 työväenopistokomitean työ, sen taustat ja mietinnön kohtalo, käy. dään läpi sitäkin tarkemmin. Näin tulee osoitetuksi sekä mietinnön luonne poliittisen murrosvaiheen tuotteena että sen vedenjakaja-asema opistolaitoksen käännekohdassa. Näkemys yhteiskunnallisesta kasvatuksesta opistojen ensisijaisena tehtävänä ja opistojen työväenhenkisyydestä testautuu sodanjälkeisessä yhteiskunnassa auttamatta vanhentuneeksi ja epärealistiseksi. En ole aivan samaa mieltä Karsikkaan kaikista tulkin. 
noista, en varsinkaan puoluepoliittisista kytkennöistä, mutta olennaiset tekijät hän on taiten seulonut sekä mietinnössä että sen synnyttämästä keskustelusta.

Selvitellessään 1960-luvun alun lainuudistusta Karsikas on ehkä turhaankin persoonallistavasti kuvannut joidenkin vaikuttajien osuutta lain aikaansaamiseen ja muotoutumiseen, mutta kylläkin tämä kuvaus "miten lainuudistus runnattiin läpi" kirjaan viemisen arvoista tietoa sisältää. Valtion toimet vuoden 1962 lain jälkeen on tässä yhteydessä kuitattu lyhyesti: kansalaisopistotoimikunnan mietinnön (1971) arviointi on poleemisuuteensa nähden ylimalkainen.

Kolmannen luvun loppujaksoissa keskitytään opistoliikkeen painostustoiminnan ja valtion kontrollin erittelyyn. Nämä pitkälti kvantitatiivista todistelua tavoittelevat osaanalyysit eivät oikein nivoudu yhteyteensä ja tekijä ilmeisesti liioittelee niiden merkitystä työnsä kokonaisuudelle. Vapaata sivistystyötä edustavien poliitikkojen toiminnasta eduskunnassa ja hallituksessa kertyy sinänsä kiintoisaakin ainesta, mutta epäselväksi jää, miten päin havaintojen tulisi valaista kysymystä opistolaitoksen ja valtiovallan suhteista. KTOL:n vaikutusyritysten erillinen kirjaaminen on hiukan luettelonomainen ekskursio. Tämä aineisto, samoin kuin katsaus Opistolehden kirjoitteluun olisi ehkä voitu antoisammin käyttää osana kunkin muutosvaiheen kokonaistarkastelua.

Yleistävä väite valtion kontrollin tiukentamisesta tulee heikosti perustelluksi, kun pääargumentaationa on kouluhallituksen kirjelmien ja virkakunnan määrällinen kasvu. Kontrollin muutosten arvioiminen olisi edellyttänyt systemaattista kirjelmien sisällön ja intentioiden analyysia. Tekijä ei suhteuta hallintotoimien kasvua opistolaitoksen ja sen toimintojen kasvuun eikä paneudu riittävästi siihen, mitä tarkoituksia ja seurauksia oli hallintotehtävien siirtämisellä lääninhallituksiin.

Tutkimuksen toisena päätehtävänä on osoittaa opintoainerakenteissa tapahtuneiden muutosten perustalla, miten opistojen tosiasiallisesti toteuttama tehtäväkuva on muuttunut suhteessa normatiiviseen tehtävänmäärittelyyn. Varsinainen analyysi rajoittuu saatavilla olleen aineiston ehdoin vuosiin 1946-79 - jo tämänkin aineiston kerääminen ja käsittely on vaatinut mittavan työmäärään. Tärkeimpänä tuloksena Karsikas saattaa todentaa, että huomattavat muutokset opintoainerakenteessa ja siten tehtäväkuvas- jälkeen ja merkittävässä määrin sen välittömänä välillisenä seurauksena. Päätulosten luotettavuuteen minulla ei ole merkittävää huomauttamista. Yksityiskohtiin mentäessä on $\mathrm{mm}$. tilastointitavassa ja tilastojen käytössä monenkinlaista moitteen sijaa. Ainerakenteen muutosten seuraamisessa, minkä lähtökohdaksi olisi pitänyt ottaa vasta vuosi 1950, on "kasvuprosenttien" laskeminen ollut pikemmin haitaksi kuin hyödyksi. Selkeämpi kuva muodostuu, kun verrataan sellaisinaan aineluokittaisia jakaumia kunkin vuosikymmenen vaihteessa. Suurten aineluokkien prosenttiset suhteet osoittavat varsin karkeasti tehtäväkuvan muuttumista. Vähintäänkin luotettavuuden arvioinnissa olisi tullut kiinnittää huomiota niihin sisällöllisiin muutoksiin, joita tapahtuu aineluokkien sisällä (esimerkiksi ns. yhteiskunnallisissa aineissa). On myös huomattava, että esimerkiksi vieraitten kielten opetus- ja opiskelijamäärä on absoluuttisesti kasvanut, vaikka joidenkin muiden aineiden opetuksessa samanaikaisesti tapahtunut kasvu pienentää prosenttiosuutta.

Karsikkaan käsite perusaineet, joka pohjautuu opistojen alkuvaiheiden tehtävänmäärittelyyn, on altis subjektiivisille tulkinnoille. Vielä subjektiivisempi on tekijän kehittämä opintoaineiden ihannejakauma. Sinänsä idea - ainerakenteen tietyn tasasuhteisuuden asettaminen ideaaliksi - on järkevä ja työhypoteesin tapaisena arviointivälineenä malli näyttää käyttökelpoiselta.

Tehtäväkuvan muuttuminen on asianmukaisesti pyritty kytkemään yhteiskunnan kaupungistumiseen, opistojen leviämiseen maaseudulle ja muuhun kokonaismuutokseen - käsittelytapa on tosin aika tavalla suurpiirteinen.

Karsikkaan käytössä on ollut Kosti Huuhkan tekemä, toistaiseksi julkaisemattoman kansalaisopistolaitoksen historian käsikirjoitus (osia). Hänen oma työnsä itsenäisyyttä tai tekstinsä omaperäisyyttä ei kuitenkaan ole mitään syytä epäillä.

Raportin päätösluku on suurelta osin aikaisemmissa luvuissa esitetyn tiivistelmää. Kokoavat päätelmät ovat yllättävän pyöreitä ja ikäänkuin alistuneita, minkä syyksi voisi arvailla opistotoiminnan ja valtion säätelyn viimeaikaista kehitystä - kehitys näyttää nimittäin vievän etäälle Karsikkaan esittämistä ideaalimalleista. 
Tutkimuksen esitystapaa ja raportin asua olisi pienelläkin viimeistelyllä voitu huomattavasti kohentaa, mutta sille on tekijän terveydentilan heikkeneminen asettanut esteensä.
Kaiken kaikkiaan Karsikas on tehnyt merkittävän pioneerityön kansalaisopistojen tehtävien historiallisen kehityksen tutkimuksessa ja tuottanut samalla mm. valtion säätelystä tietoa, joka tarkentaa suomalaisen aikuiskasvatuksen muutostaustaa laajemminkin.

Tampereella 24.11.1989

AULIS ALANEN 